International Journal of English Language Studies (IJELS)

ISSN: $2707-7578$

DOI: $10.32996 /$ ijels

Website: https://al-kindipublisher.com/index.php/ijels

\title{
The Hoax News Text On Social Media: A Critical Discourse Study
}

\author{
Kholid ${ }^{1} \square$ Ketut Darma Laksana ${ }^{2}$ and Nengah Sudipa ${ }^{3}$ \\ ${ }^{1}$ Lecturer of Indonesian Language, Hamzanwadi Mataram, Mataram, Indonesia \\ ${ }^{23}$ Lecturer of Linguistic Program, Udayana University, Denpasar, Indonesia
}

$\square$ Corresponding Author: Kholid, E-mail: kholidid3@gmail.com

\section{ARTICLE INFORMATION}

Received: 17 September 2021

Accepted: 16 October 2021

Published: 20 October 2021

DOI: 10.32996/ijels.2021.3.10.3

\section{KEYWORDS}

Hoax Text, Social Media, Critical

Discourse

\section{ABSTRACT}

The phenomenon of using language in cyberspace or social media has indeed a trend with various contemporary applications, with the aim of being more effective and efficient in communicating. The benefits of technology cannot be reached by its advantages and besides that, it also cannot be ignored from the negative side. It is possible that with various applications, it is easy to spread fake news text on social media. The text of fake news on social media, information in this study is used as a data source and at the same time used as an object of study on Facebook, WhatsApp, Twitter, and other media accounts. The aim of this study was to describe in depth the problem of the phenomenon of the spread of fake news texts on social media, this is adjusted to the problems raised in this study. The purpose is to find out and analyze the language criteria used in hoax text news texts on social media. This research was a type of qualitative descriptive research. By using van Dijk's version of the critical discourse study theory as a theoretical framework with the aim of revealing the phenomenon of language use in depth, both micro and macro, with the point of view of discourse as a text, social cognition, and context. Furthermore, methods and the techniques of data collection in this study. As the first step by way of observation, the next step was documentation that was supported by instruments in the form of questionnaires and analysis tables. Based on the results of data analysis, several things were found as follows: (1) criteria for hoax news texts on social media, consisting of (a) fake news texts on $\mathrm{S}$ social media are only humorous; (b) have low modality (c) motivation to want to cheat relatively (d) have incomplete information (e), not high plagiarism. Thus all of these things are indeed true empirically that the condition of the text of hoax news on social media is as described previously. All of this has become a widespread discussion regarding the concept of hoax news itself.

\section{Introduction}

Information or news was needed by everyone because without information, life will not have a change in adjusting the development of the picture of a situation or living condition in the past, present, and future. Information or news was initially easy to obtain. This is due to the development of science and technology so rapidly in the current era of digitalization.

The development of science and technology does have a tremendous impact in today's life, including the positive impact that it is easier for someone to get information or news with various media, both print, electronic and other media. On the other hand, the development of science and technology in the modern era is very supportive from various aspects in carrying out daily activities, such as in aspects of education, social economy, and culture.

The information or news was very easy to obtain for everyone because it was easily and quickly accessed with the desired goal, one of which is through social media in the current digitalization era. Social media is indeed very beneficial from two sides, the newsmaker or news presenter in conveying information with a specific purpose, and the news connoisseur or netizen actor in receiving the desired information.

Copyright: (C) 2021 the Author(s). This article is an open access article distributed under the terms and conditions of the Creative Commons Attribution (CC-BY) 4.0 license (https://creativecommons.org/licenses/by/4.0/). Published by Al-Kindi Centre for Research and Development, London, United Kingdom. 
Information stability was marginalized by information that was far from existing facts because this is due to personal or group interests by reconstructing previously established information into vague or vague information and being buried by hoax information or fake news itself. It was true that hoax news is currently rife with various factors or specific goals that cause the appearance of the presentation of hoax news texts (hereinafter briefly $\mathrm{HN}$ ) for example economic, social and political factors. As for the Hoax news $(\mathrm{HN})$ texts that often appear so far, indeed a variety of information was presented, both information about religious, cultural, economic, educational, social, and political content.

The phenomena of using language both through traditional and modern media have occurred in the midst of diverse societies. All of these things are very interesting to research and can be observed through hoax news texts on social media (hereinafter briefly referred to as HNTSM). The situations and conditions like this can only be carried out with an intensive study of discursive texts, for example, through a critical discourse analysis approach (CDA).

\section{Literature Review}

The theoretical basis used in this research is the study of critical discourse. The critical discourse analysis (CDA) study was a form of discourse analysis in which one of the studies analyzes the practice of power. The concept of power here was a tool used to control something. In this case, the form of discourse was connected with society. This means that discourse can be a form of power practice in the midst of society. In addition, The CDA has its own characteristics including: paying attention to social problems, power relations are discursive, or exist in discourse, discourse plays a role in the formation of society and culture, discourse plays a role in building ideology, discourse is historical, discourse also mediates the relationship between text and social society, discourse is interpretive, explanatory and discourse is a form of social action. However, in this study, the discourse study used the van Djik version. van Djik's critical discourse perspective, the concept of discourse that is built and developed in the perspective of the text, context, social cognition.

Based on all of this, the researcher needs to convey several research points that were considered relevant to previous research, both in terms of the object of research and the same study. Thus, for more details, it can be seen in the description of the relevant research below.

First, Maulana (2017) with the research title "Kitab suci dan hoax: Pandangan AL-Quran dalam menyikapi berita bohong." (The holy book and hoaxes: The view of the Koran in dealing with hoax news.)" This research study only focuses on AL-Quaran's view of the BB phenomenon. The approach used is a descriptive method and the study is to explain that the Al-Quran as a guide needs to be analogized again with today's Islamic society. By judging from the object of study, there are similarities in researching the phenomenon of hoax news from a legal perspective, both religious law and state law.

In addition to these studies having similarities, there are also differences that are clearly visible, if you pay attention to the methods used. The method used in the research is a qualitative descriptive approach with the object of the research being the text culture of HNTSM. This was studied from the language aspect through an approach or looking at the perspective of critical discourse analysis. This research has contributed to researchers in terms of the BB hoax phenomenon from the point of view of religious law which according to the researcher greatly enriches the wealth of information about the hoax news.

This study examines the phenomenon of language use on social media with the issue of $\mathrm{HN}$ distribution with a qualitative descriptive approach and critical discourse analysis as a scalpel or theoretical basis. This is the point of difference with previous research that focuses on the HN phenomenon in the Islamic concept that applies the values contained in the Al-Quran.

Second, the research conducted by Albaburrahim (2017) with the title "Analisis Wacana Kritis Pada Pemberitaan Kasus Papa Minta Saham di Metro TV" (The Critical Discourse Analysis on Reporting on the Papa Asks for Shares Case on Metro TV)". This research uses a critical discourse analysis approach as a scalpel to examine the phenomenon of language use in Metro TV reporting. The news aspect that became the focus was related to the discourse aspect and the sociocultural aspect related to the coverage of the "papa asking for shares" case on Metro TV. The method used in this research is a descriptive method, which is a method that describes the phenomenon of an object under study. This research was also a type of qualitative research. Fairclough's critical discourse analysis approach was applied in three stages, namely text analysis (descriptive), interpretation, (discourse practice analysis), and explanation (sociocultural practice analysis).

The difference in the research focuses on the analysis technique and the object of the study, namely seeing the phenomenon of Metro TV reporting, while this study examines the phenomenon of language in social media, especially aspects of HN culture and law. When viewed in terms of analytical techniques, previous researchers used Fairclough's version of critical discourse analysis as a reference to explore this phenomenon. In this study, van Dijk's version of the analysis technique was applied as a reference in 
analyzing the phenomenon of using social media language. However, both of these studies used the same research method, namely a qualitative descriptive approach.

\section{Methodology}

This research was conducted with a qualitative method approach because it reveals and understands, as well as analyzes, the text, and context of hoax news on social media. $\mathrm{HN}$ is distributed by social media users (netizens) or $\mathrm{HN}$ creators with certain motives, and the problem will be revealed in depth in the next section or in the data analysis section.

\subsection{Types and Sources of Data}

This research has the type of research data in the form of qualitative data in the form of HNTSM. The text on social media became the data in this study. This will be studied from the perspective of critical discourse initiated by van Djik. The purpose of the researcher to use a critical discourse analysis approach was to answer all problems regarding the phenomenon of language use in social media. This was in accordance with the type of data to be studied, namely qualitative data because it was abstract and ambiguous. The source of data in this study is HN text which is widely spread on social media through Facebook, Whatsapp, Twitter, and other social media accounts. This is the object of research.

\subsection{Instruments}

The previous researchers will describe the things that supported the data collection process. Indeed, in the explanation in every research there must be elements that support, to assist in the research process. All of these things were very much needed by every researcher in revealing a phenomenon about the conditions to be studied. Such phenomena are called research instruments or tools.

Based on the argument above was in accordance with Arikunto's opinion (2002: 136) which states that "research instruments are a supporting tool to facilitate the data collection process that aims to achieve more optimal, comprehensive and systematic results so that they are easier to process".

\subsection{Data Collection Techniques and Methods}

This research includes research conducted with a qualitative approach method. The purpose of this study is to understand and reveal the phenomenon of language use in social media that is contemporary in nature by looking at the HN text. This research should be carried out through a qualitative approach as a method.

Indeed, this research was a study in the form of discourse texts on social media that cannot be dammed by anyone. This has become a culture in the use of social media in the digital era and the current democratic era. In addition to the methods applied in this study, the next step was data collection techniques. The first steps were taken by the researcher as the initial step in data collection, observation, and documentation.

\section{Results and Discussion}

The problem of hoax news texts on social media has several criteria, which can be seen from a linguistic perspective, and according to researchers, it was very necessary to describe in this section. However, the HN criteria referred to criteria of hoax new in terms of language packaging, in terms of form and function. This was studied from the perspective of critical discourse which includes discourse as power and social context. The problem in this study as well as the initial analysis in this section was about the criteria for the HNTMS text. The HN criteria, in the opinion of the researcher, do have several criteria that researchers need to describe in this section. This can be seen in the table section below.

Table 4.1: The Criteria for Hoax News Text on Social Media

\begin{tabular}{|l|l|}
\hline No & The Criteria for Hoax News Text on Social Media \\
\hline $\mathbf{1}$ & HNTSM or Hoax information that has motivation to deceive is relatively \\
\hline $\mathbf{2}$ & HNTSM or Hoax Information that was chain \\
\hline $\mathbf{3}$ & HNTSM or Hoax Information that was high non-plagiarized \\
\hline
\end{tabular}

Based on table 4.1 above, a description of the criteria or benchmarks was something that can be said to be HNTSM. This was evidenced by the results of responses from respondents made by researchers in the form of a questionnaire form that has been 
distributed with a nominal percentage of each BB criteria. All the criteria listed in the HNTMS texts were described by the researcher in detail, the explanations of which can be noted below.

\subsection{HNTSM Texts or Information Hoaxes That Have Motivated Wants to Be Relatively Deceptive}

The HNTSM text which was part of the motivation that was deceptive for a moment because this text tempts netizens who have data change content to be sent to Bank BRI with complete ATM no data that was widely spread on social media. This content was confusing and the curiosity of netizens. There was an attempt to find accurate facts to related parties by being ordered to contact BRI's contacts and submit personal data. This can be seen in the HNTSM text section below.

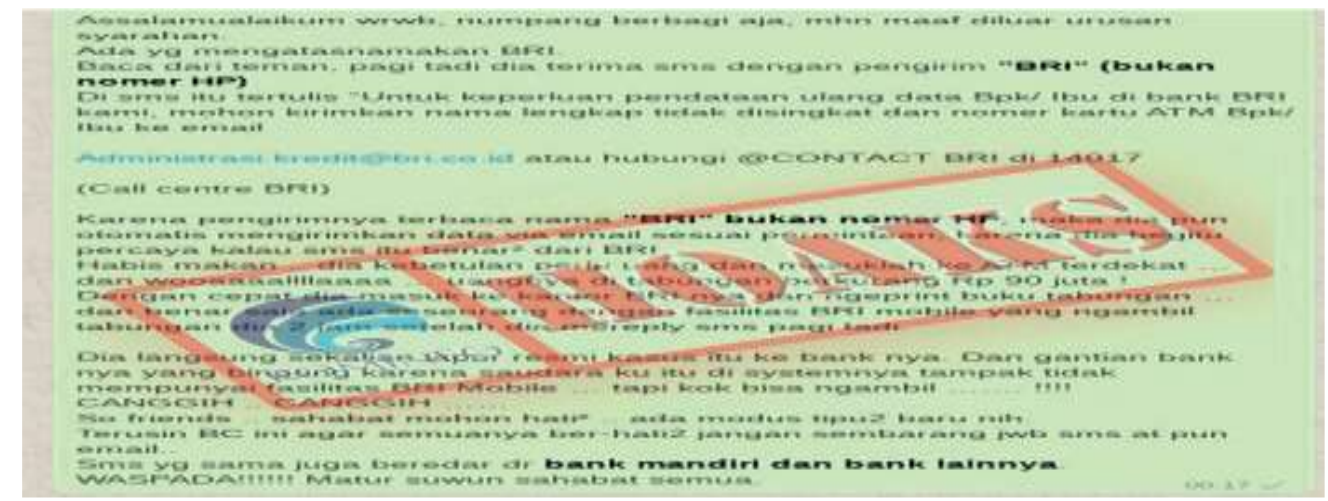

\section{Microstructure Analysis}

Syntax: Short messages sourced from one of the social media namely Whatsapp, in the form of chain messages. The message was presented in the HNTMS text in the form of active sentences, this was used to strengthen the content of related information. Besides that, the text of the HNTMS was a statement from someone that contains data entry from Bank BRI.

The HNTMS text in this section is a narrative text from the context of events related to gifts from Bank BRI. If you pay attention to the end of the text, it was a command sentence and an appeal. This is displayed aiming to be understood by netizens to be more careful because in the text the beginning of the sentence used was in the form of a command sentence, then at the closing and at the end of the text, it was an appeal. Thus, it was intended that netizens remain vigilant regarding the information referred to by the producer.

Stylistics: The diction used was in the form of words related to banking matters. The choice of words is used in the form of the word "full name of the institution, not an abbreviation". This word was used as an emphasis to build a meaning that is proven that this problem is very necessary and very important to be followed up.

The choice of the word "BRI is not a cellphone number" was presented in the text as the subject, namely the organizer or implementation of the activity in the form of the data content. These words were chosen and presented as a form of reinforcement that the provider has no level of the doubt for customers to fill in the data as requested because the institution is legal.

Another word that is presented in the form of the word "BRI Mobile" was shown because this word is seen with a global meaning that not everyone knows about the meaning of the word choice itself. This is the producer's strategy in presenting the HNTMS text to netizens.

Rhetorical: The appearance of a text was highly dependent on the presentation and symbolic connection of meaning. As for another display of the text in the HNTMS text, namely the use of bold letters on the word "BRI, not a cellphone number". This word is displayed in bold letters with the aim of being a form of emphasis and there was a meaning that wants to be built in the form of a high modality owned by the related party which was conveyed to netizens because this was direct contact with the related party, not a personal number with a low level of credibility.

The text presented in this section was the use of capital letters for the word "CANGGIH-CANGGIH". This word is printed in capital letters as a producer's strategy in presenting a message that emphasizes the meaning of a situation that may occur beyond one's expectations due to rapid technological advances.

In addition to sophisticated words printed using capital letters in the form of the word "WARNING". Thus this word is presented by the producer, while the meaning it has a message in the form of an appeal to remain careful in the same context. This was 
reinforced by the emphasis on the presentation of the words "banks independently and other banks". This word is in bold as a form of emphasis to always be aware of the same problem.

$\mathrm{HN}$ text: The HN text category contained in all narrative texts was only a mere fictitious argument because it was very concrete that the text presented looks awkward when checked on the portal.

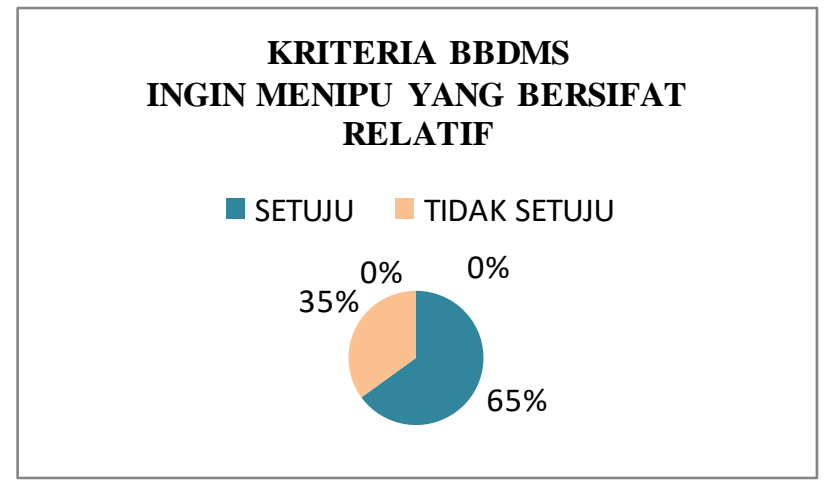

Chart 4. 1 Criteria for HNTSM to Deception are Relative

The chart above was the result of the percentage of respondents selected by researchers with an intellectual interpretive community of 19 people. The average education, they are pursuing doctoral education in various fields. This was in accordance with Darma's opinion which states that in addition to the criteria for hoax news, for strengthening, it was necessary to clarify the ten informants who are referred to as the "interpretive community" (see Laksana, 2018).

\subsection{Analysis of HNTSM Text or Information Hoax with Chains}

The text of the HNTSM was still dealing with things that are harmful to health contained in the drink entitled "the Pepsi company's beverage ingredients are contaminated with HIV blood". The impact of the BBDMS text can be seen in the text below.

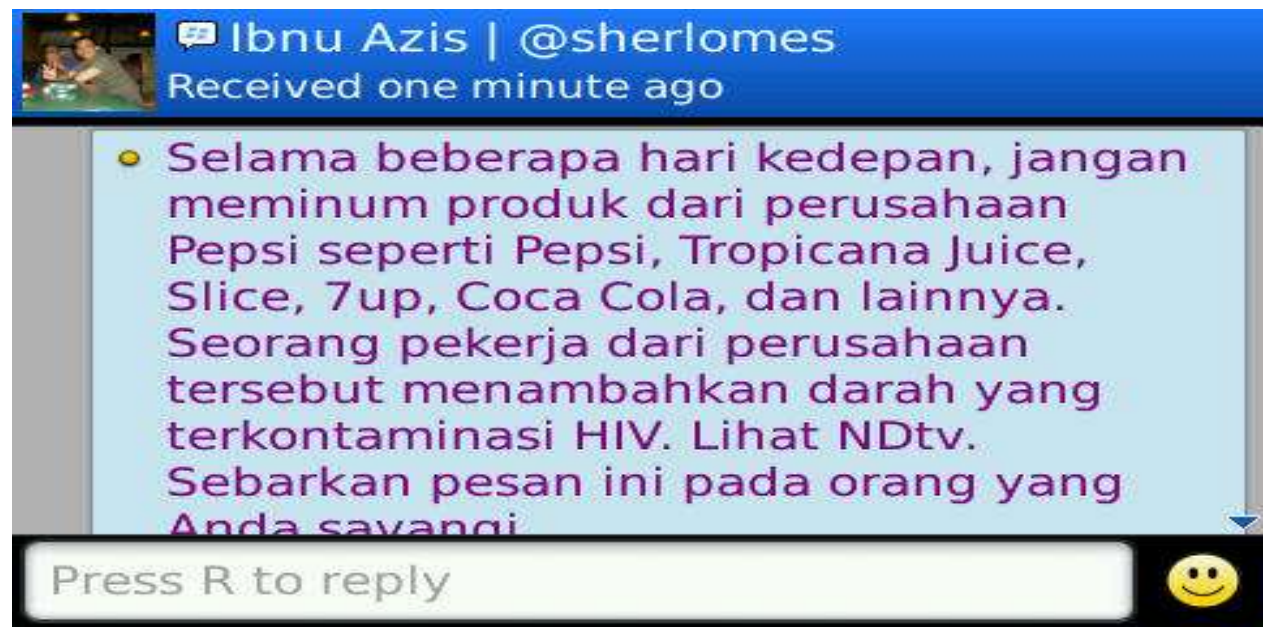

Figure 4.1

Verbal Language Features About the Dangers of Pepsi Drink

Based on the picture above, the text of HNTSM contains one of the ingredients of a drink that was contaminated with HIV. The public responded that the text easily believed that the ingredients for Pepsi drinks were contaminated with HIV. Indeed, in terms of social context, first, this shows that there was an indirect impact on the people who consume the drink. Second, the emergence of unhealthy economic competition as a form of someone's motive to drop the Pepsi company's product. This shows evidence that the text of HNTSM was massively spread in the community and this can have an impact on social conditions universally.

\section{Microstructure Analysis}

Syntax: HNTSM text was just information containing a short message regarding a form of prohibition sentence about drinks from the Pepsi company. This was supported by the use of active sentences with the aim as if the incident actually occurred related to 
the problem of additional blood contaminated with HIV drinks from the Pepsi company. The words referred to in the use of active sentences include the word "drink, add" this word indicates an action that has been carried out at a certain time.

Semantics: The meaning contained in the BBDMS text in the form of a short message was conveyed through one of the BBM accounts. Ibn Aziz has spread widely in chains. Lexically, the condition of the BBDMS text implies a prohibition against drinking any type of beverage from the Pepsi company because it has been added to blood contaminated with HIV. However, grammatically, the text of the BBDMS contains only information that only urges you to be careful with red drinks because they are thought to have been mixed with HIV blood.

Stylistics: The choice of words displayed in the BBDMS text appears from a menu in the form of the word "HIV". Presented in capital letters with the aim of describing things that originate from a problem that was considered very dangerous. Another choice of words in the BBDMS text presentation was a brand of fizzy drink. This word was displayed with the aim that material or liquid was easily mixed with various colors, namely red. All of these things become the motive for presenting the choice of words with the aim that an event can be accepted by common sense.

HN text: HN text object lies in the process of mixing or being contaminated with HIV. Based on the results of the search for the information data that the text of the information was only fictitious because of the process of transmitting the HIV virus through blood. Blood in the sense through transfusion. Not blood through drinking. For more details, please pay attention to the clarification of factual and reliable information through relevant sources, both in the context of the problem and the phenomenon of the digitalization era.

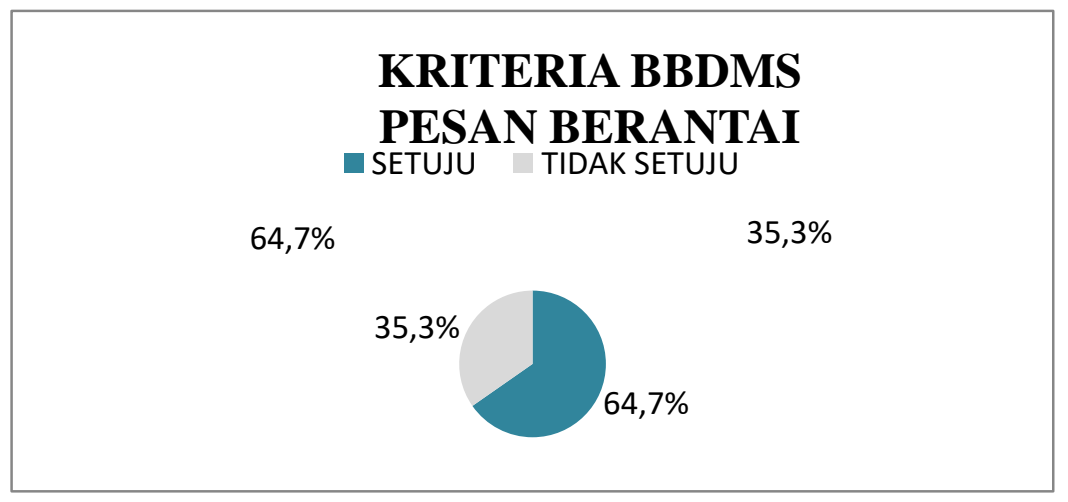

Chart 4. 2 Criteria for Chain Message HNTSM Text

The chart above illustrates the criteria for HNTSM text which was a chain message. All of this was evidenced by the criteria for the HNTSM text in the form of a chain message, it can be proven by the results of the responses from the interpretive and correspondent communities in the form of a questionnaire, it was found that the percentage agree and disagree with the criteria for the HNTSM text. In accordance with the results of the respondents ' responses, all of them reached $64.7 \%$ who agreed and disagreed with $35.3 \%$ of the questions about these criteria.

\subsection{Analysis of HNTSM text data High Non-Plagiarism Information}

The HNTSM text in this section was included in the category of high non-plagiarism information. The context of the message that producers wanted to convey to netizens was in a scientific context, namely the health side. However, all of these things do not describe a reference in the delivery of information related to the text as a reference in the description of health context information. An example of a part of the HNTSM text in the high non-plagiarism category can be seen in the data section below. 


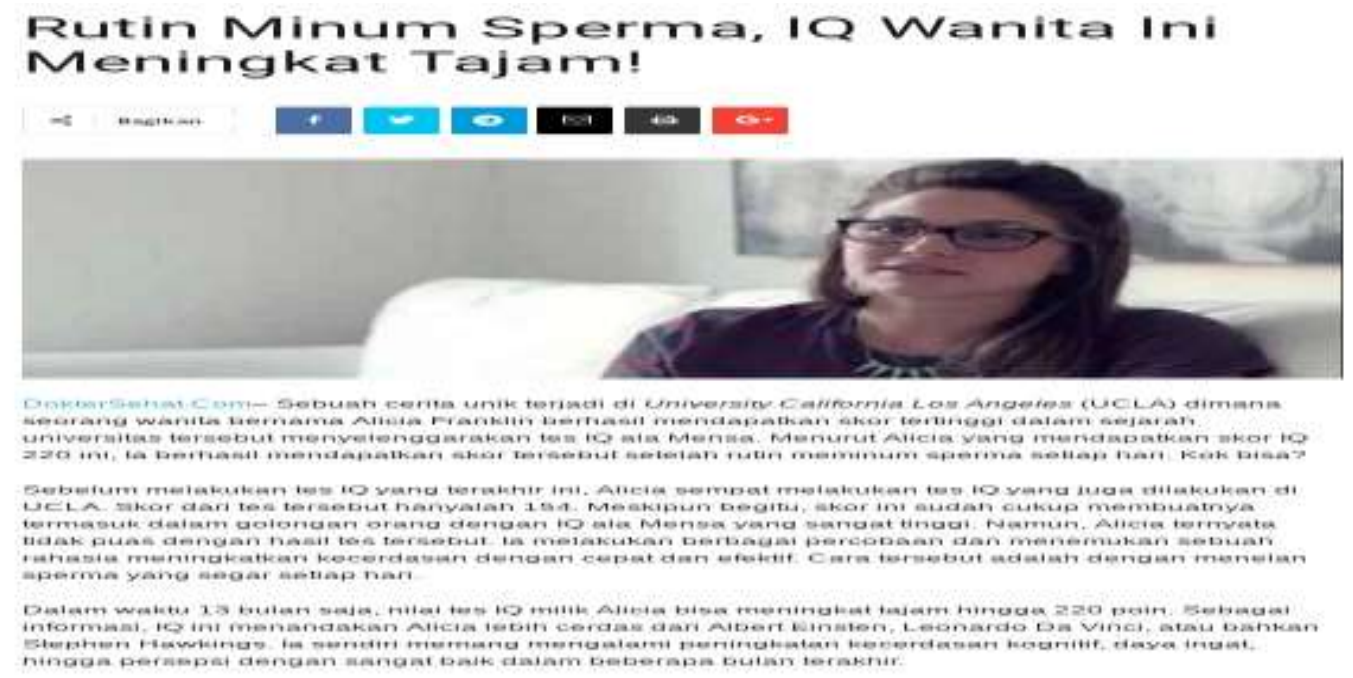

Figure 4.11

Women's IQ Sperm Drinking Routine

\section{Microstructure Analysis}

Syntax: It was clear in the HNTSM text in this section the sentence pattern used was information in the form of a message about the health context whose text presentation was in the form of an active sentence. Thus, it was used by producers to strengthen the message they wanted to convey to netizens, as factual information.

The sentence in the text includes an argument that was narrative in the context of conveying a causality of an event to be conveyed in the HNTSM text. All of these things are a strategy from producers in presenting texts with arguments that seem undoubted to netizens.

Stylistics: The choice of words used in this HNTSM text, in the form of the words "routine, drinking, sperm, IQ, and women". All these word choices are displayed in the text by the producer with the aim of emphasizing an event in the form of an action described with causality starting from the action and the significant changes that occur.

Rhetoric: The presentation of the text in the HNTSM text in a rhetorical element appears to be presented in the form of the words "IQ and UCLA" and the words "Dokter Sehat.Com". All of these dictions were displayed in capital letters and colored blue with the aim of being the subject matter of events and sources of information where the text was published or news sites. Another display from another rhetorical part is an image of a woman wearing glasses. The image was presented combined in the HNTSM text with the aim of supporting a narrative in the HNTSM text.

HN text: the HN text in the HNTSM text in the high non-plagiarism category was located at the wrong source of information or website address because it does not match the intended site address.

Based on the description of the criteria for the HNTSM text, one of the pieces of information was classified as high non-plagiarism. The researcher proves that the results of the responses from the interpretive community and through a questionnaire, the percentage agree and disagree with the criteria for the HNTSM text, there are respondents who agree it reaches $48 \%$ and those who disagree $52 \%$. For more details, see the chart of response results from correspondent criteria for HNTSM text as nonplagiarized information below.

\section{Conclusion}

Based on the results of the study through the process of critical discourse analysis carried out by researchers in this study with the $\mathrm{HN}$ text as the object of study spread on social media with a focus on the HN text criteria discourse. Based on all of this, the researcher can describe the main conclusions that can be drawn. That the HNTSM text has criteria that include a text that has the motivation to want to deceive was relatively based on the percentage of $65 \%$ respondents who said they agreed that the HNTSM text. The text of HNTSM was only chain information with evidence from the percentage of respondents $64.7 \%$ who said they agree. The text of HNTSM information was not comprehensive with the results of $70.1 \%$ of respondents who said they agree. The text of HNTSM information that has no confusion or non-plagiarism is high with the results of $48 \%$ of respondents saying they agree. All 
criteria for the HNTSM texts were in the form of HN text which is spread on social media through Facebook, WhatsApp, and Twitter accounts as well as other social media.

The appearance of HNTSM text was in the form of text-only or verbal elements and text accompanied by pictures or non-verbal elements which are strategies from information or newsmakers in the context of HNTSM that were widespread without restrictions that can be accessed by all circles of society. Thus, this was still related to the criteria for HN text which has the potential to cover or divert attention in presenting information by displaying text in the form of text information accompanied by images with motivation so that the information or news has high modality and convinces netizens and vice versa that the appearance of HN text was very had the potential to be manipulated into an informational text that was far from the original habitat of the truth of the information.

Acknowledgments: The author would like to thank and appreciate those who have contributed to this current study, especially the supervisors: (1) Prof. Dr. I Ketut Darma Laksana ; (2) Prof. Dr. I Nengah Sudipa for their criticism, comments, and suggestions which has contributed to the maximum completion of this study.

\section{References}

[1] Albaburrahim, A., \& Sujinah, S. (2017). Analisis wacana kritis pada pemberitaan kasus papa minta saham di Metro TV. Lingua Franca: Jurnal Bahasa, Sastra, dan Pengajarannya, 1(2).

[2] Bossio, D. (2017). Journalism and social media: Practitioners, organisations and institutions. Springer.

[3] Bell, D. (2006). An introduction to cybercultures. Routledge.

[4] Creswell, J. W., \& Creswell, J. D. (2017). Research design: Qualitative, quantitative, and mixed methods approaches. Sage publications.

[5] Eriyanto. (2001). Analisis wacana: pengantar analisis teks media. LKiS Yogyakarta.

[6] Gunawan, B., \& Barito, M. R. (2021). Kebohongan di Dunia Maya. Kepustakaan Populer Gramedia.

[7] Halliday, M. A. K., \& Hasan, R. (1992). Language, Context and Text: Aspects Of Language In a Social-Semiotict Perspective (Diterjemahkan oleh Asruddin Barori Tou \& M. Ramlan dengan judul Bahasa, Konteks, dan Teks: Aspek-Aspek Bahasa dalam Pandangan Semiotika Sosial). Yogyakarta.

[8] Halliday, M. A. K., Matthiessen, C. M., Halliday, M., \& Matthiessen, C. (2014). An introduction to functional grammar. Routledge.

[9] Harley, D. (2008). Common Hoaxes and Chain Letters. San Diego: ESET, LLC.

[10] Hamdan, H. WACANA DALAM PERSPEKTIF NORMAN FAIRCLOUGH.

[11] Nurdiarti, R. P. (2019). PENDIDIKAN KARAKTER DALAM PERSPEKTIF ETIKA KOMUNIKASI DI ERA MASYARAKAT INFORMASI. KoPeN: Konferensi Pendidikan Nasional, 1(1), 115-123.

[12] Peters, C., \& Broersma, M. J. (Eds.). (2013). Rethinking journalism: Trust and participation in a transformed news landscape. Routledge.

[13] Peltola, J. (2003). Kaksi näkökulmaa 2000-luvun teledemokratiaan. Kulttuurintutkimus, 20(4), 35-46.

[14] Van Dijk, T. A. (2001). Discourse, ideology and context. 